\title{
New "stars" of global economy: TICKS comes to replace BRICS
}

\section{Iryna Chychkalo-Kondratska}

Yuri Kondratyuk National Technical University,

Poltava, Ukraine

Email: chichkalo.irina@gmail.com

\section{Nataliya Bezrukova}

Yuri Kondratyuk National Technical University,

Poltava, Ukraine

Email: berrukova.nataliya.1976@gmail.com

\author{
Vitalii Svichkar \\ Yuri Kondratyuk National Technical University, \\ Poltava, Ukraine \\ E-mail:sva48484@gmail.com
}

Abstract. The paper discusses the reasons for the establishment of BRICS, and the role of the BRICS countries in the global economy today. Special attention is paid to the analysis of the factors, which caused the "destruction" of BRICS. The BRICS group is now being replaced by a new grouping of fast-growing economies - TICKS in which Russia and Brazil are replaced by Taiwan and South Korea. The authors analyzed the macroeconomic indicators of the TICKS countries and proposed a new structure of the grouping - Thailand, India, China, Korea, Singapore. These countries have fast-developing high-tech industries,

Received: November, 2016 1st Revision: March, 2017

Accepted: October, 2017

$10.14254 / 2$ $8330.2017 / 10-3 / 2$ increasing foreign investments and GDP, as it is proved here by the respective calculations of the authors.

Keywords: global economy, BRICS, TICKS, emerging markets, foreign investments.

JEL Classification: F01, F02, F29, O33, O57

\section{INTRODUCTION}

Globalization is the dominant trend of the world economy development nowadays. This process applies to all spheres of social life; under its influence the global economic system undergoes dramatic changes. Globalization leads to deepening world integration and speeds up all the processes occuring in the life of the world community. Thus, of changing nature are the global centers of economic development, which are attracting the most significant inflows of investments, skilled labor and innovations.

The concept of BRICS, which has united the fast-growing world markets of Brazil, Russia, India, China and South Africa, has now lost its relevance. BRICS, as a grouping of economies with high rates of 
development, has almost ceased to exist. It is now being replaced by TICKS, a new group of countries which are the new centers of foreign investment and innovations' development (Taiwan, India, China, Korea/South Korea and South Africa). Russia and Brazil are no longer the centers of the world economic development. Thus, within the global economy there appears a new group of countries with the role of "new stars" of the world economic development. They require careful analysis and evaluation of the peculiarities of their operation, and this predetermines the relevance of the study presented further.

\section{LITERATURE REVIEW}

A number of scholars have dedicated their works to the research of peculiarities of the establishment and operation of fast-growing economies of developing countries. Among them the writings of Johnson (2016), O'Neill (2001), Bootle (2013), Movchan (2015), Aslund (2016) Mamedov et al. (2016), Verner (2011), deserve special attention.

But the trends and peculiarities of the TICKS member states development require further analysis, which is the subject of research in the article.

The paper aims to an analyze the peculiarities of functioning and the main reasons for the BRICS decline and outline the directions of the development of TICKS, a new group of fast-growing economies, as well as to substantiate the causes of the emergence of TICKS* with new member states.

\section{RESULTS}

Globalization changes the global system, creating new challenges and opening new opportunities for the economy. In today's global economy there occurs a change of leading "players": the role of newly industrialized countries in the group of developing countries is enhanced, against the backdrop of economic slowdown in developed countries. Developing countries actively attract foreign direct investments, channeling investment flows into services and technology (Yerznkyan, 2016; Banioniene and Dagiliene, 2017). But recently, the group of leading players among developing countries has also changed. As the leading analysts note BRICS suspends its existence as a group of countries that have been the engine of the world economic growth, and now, a new group of "engines" of the global economic development is being formed - the TICKS countries (Johnson, 2016).

BRICS is a group that includes five rapidly developing countries, namely Brazil, Russia, India, China and South Africa. The concept of BRIC (Brazil, Russia, India, China) appeared in 2001. It was offered by Jim O'Neill, the chief economist of the Goldman Sachs bank (O'Neill, 2001). For convenience of trade in the stock market, the analysts at Goldman Sachs merged the securities of Brazil, Russia, India and China in the pool with the aim to separate them from other papers. Goldman Sachs experts believed that over time the economic growth of these countries would exceed the growth of the G7 economies. Until 2011, the BRIC acronym was used, and only since South Africa joined the group, according to the statement of the Indian Minister of Finance, the group began to be called BRICS. The term BRICS started to be used to call the grouping of countries, which should ensure future growth of the global economy.

BRICS countries occupy $26 \%$ of the globe, they are inhabited by $42 \%$ of the world's population and they produce $27 \%$ of the world GDP. Brazil, Russia, India, China produce about $40 \%$ of wheat, $50 \%$ of pork, more than $30 \%$ of poultry, $30 \%$ of beef of the global indicators. $32 \%$ of global arable land is concentrated in the BRICS countries (BRICS in Numbers, 2015).

Each BRICS country has a top industry specialization, by which it is represented in the world markets. Thus, Brazil specializes in manufacturing agricultural produce, Russia is rich in mineral resources, India has cheap intellectual resources, China - cheap labor resources, South Africa has significant natural resources. 
So, owing to the existing potential, China and India are global suppliers of labor and consumer goods, industrial goods and services, and Brazil, Russia and South Africa are dominant suppliers of raw materials. Global ranking of the BRICS countries is represented in Table 1 (Wikipedia, 2016). As you can see, these five countries are quite significant in many economic, social, political and military fields. Thus, China and India are the top ten in terms of the GDP growth.

However, the BRICS activity continues. The 9th BRICS summit was held on September 5-7, 2017 in the city of Xiamen (China). However, the final declaration contains only general proposals for the further development of integration processes between member states. As real steps to strengthen integration, it envisages an increase in the assets of the BRICS Investment Bank from 1.5 billion USD to 4.0 billion USD, which is not enough to finance significant investment projects within the organization (9th BRICS Summit, 2017).

Table 1

Global ranking of the BRICS countries, 2014

\begin{tabular}{|l|c|c|c|c|c|}
\hline \multicolumn{1}{|c|}{ Category } & Brazil & Russia & India & China & South Africa \\
\hline Area & 5 & 1 & 7 & 3 & 25 \\
\hline Population & 5 & 9 & 2 & 1 & 25 \\
\hline The rate of population growth & 107 & 221 & 93 & 156 & 158 \\
\hline Workforce & 5 & 7 & 2 & 1 & 34 \\
\hline GDP (nominal) & 7 & 8 & 10 & 2 & 28 \\
\hline $\begin{array}{l}\text { GDP (according to purchasing power } \\
\text { parity (PPP) }\end{array}$ & 8 & 6 & $4(3-2015)$ & $2(1-2015)$ & 25 \\
\hline GDP (nominal) per capita & 53 & 56 & 138 & 94 & 71 \\
\hline GDP (PPP) per capita & 71 & 51 & 127 & 93 & 77 \\
\hline GDP (real) growth rate & 15 & 88 & 4 & 5 & 17 \\
\hline Human development index & 73 & 55 & 119 & 89 & 110 \\
\hline Export & 18 & 11 & 16 & 1 & 36 \\
\hline Import & 20 & 17 & 11 & 2 & 34 \\
\hline Balance of trade & 187 & 4 & 169 & 1 & 179 \\
\hline Foreign direct investment & 11 & 12 & 29 & 5 & 31 \\
\hline Gold and foreign exchange reserves & 7 & 3 & 6 & 1 & 33 \\
\hline External debt & 28 & 24 & 26 & 23 & 45 \\
\hline State debt & 47 & 122 & 29 & 98 & 88 \\
\hline Military spending & 12 & 3 & 10 & 2 & 43 \\
\hline Strength of the armed forces & 14 & 5 & 3 & 1 & 59 \\
\hline Railway system & 10 & 3 & 4 & 2 & 12 \\
\hline The network of roads & 4 & 8 & 3 & 2 & 18 \\
\hline
\end{tabular}

Source: Own calculations based on Wikipedia.

So the questions arise: why a group of potentially strong economies ceases to exist; why Brazil and Russia left the group of countries which had to contribute to developing the world economy?

Despite the illusory importance of BRICS, a priori, this group could not survive for long: the memberstates had far more differences than similarities. Russia should especially be distinguished. According to Roger Bootle, the analyst of the Capital Economics, a macroeconomics research firm, in Russia, unlike the other BRICS countries, GDP growth was caused not by the transformation of the economy, but a set of independent of the state factors. The main factor among them is the raising prices for raw materials, particularly oil. Russian society is still corrupt and demography shows negative trends (Bootle, 2013). 
Significant differences and asymmetries of the BRICS countries development can be traced in various areas. Thus, according to the official data, 3 billion 62 million people now live in the BRICS countries. But they are distributed very unevenly: most people live in China and India, and Russia only accounts for 5\% of the BRICS population.

The combined BRICS GDP is 17.1 trillion USD. China's GDP is 11.2 trillion USD, India's GDP - 2.3 trillion USD, Brazil's GDP - 1.9 trillion USD, Russia's GDP - 1.4 trillion USD, South Africa's GDP 324 billion USD. Thus, China produces $65 \%$ of the combined GDP and Russia only $8 \%$ of it.

All of the BRICS countries have low foreign debt (15\% - 35\% of GDP) and significant gold and foreign exchange reserves (15\% - 37\% of GDP). However, the reserves of Russia are sharply reducing, and it may become a net borrower.

Russia, unlike the other BRICS countries, is a leading exporter of mineral resources (oil, gas). However, a gradual shift to alternative energy sources will significantly reduce the competitive advantages of Russia and its impact on the global economy. At the same time, competitive advantages of other countries are going to increase. Prices for raw materials will remain low for one or two decades (Movchan, 2015; Balitskiy et al., 2014; Szurlej et a., 2015). This critical situation with the prices for raw materials will make a negative impact on the economies of developing countries which are exporters of raw materials. Their foreign exchange earnings will decline, which will probably lead to many debt crises. Brazil should especially be distinguished in this respect, as it has a large state debt and budget deficit. The raw material orientation of exports of most BRICS member countries can be considered a source of the BRICS comparative advantages, but the main countries importing this raw material are not part of the BRICS.

The BRICS countries are fundamentally different in terms of economic policy and social structure. Thus, according to the rating of Global Index of Economic Freedom, South Africa is in the 72nd place (a country with a relatively free economy), Brazil - in the $118^{\text {th }}$ place, India - in the $128^{\text {th }}$ place, China - in the $139^{\text {th }}$ place, Russia - in the $143^{\text {th }}$ (among countries with totally not free economies) (The Heritage Foundation, 2016). In Russia, there is almost no effective opposition, China has banned Facebook, free movement of people and capital, India maintains caste system, racial conflict is actual in South Africa and Brazil's main challenges are poverty and crime. In other words, the countries are quite different in their approach to the development of the economy and society, with all of them having significant problems in these areas.

The countries also differ in their standard of living. Russia is the BRICS leader in the population income. Thus, only $5 \%$ of the Russians live on 4 and less USD a day, while in Brazil $-21 \%$, China $-49 \%$, South Africa - 50\%, India - 91\% (Movchan, 2015).

The BRICS countries are characterized by inefficient management (Transparency International, 2016). Transparency International, the international organization fighting against corruption, by the corruption perceptions index, puts South Africa in the 61st place out of 175 countries, Brazil and India in the 76th place, China - the 83th place, and Russia - the $119^{\text {th }}$ place. Inefficient management significantly limits the opportunities for further development. To fight corruption it is necessary to get rid of corrupt leaders, which requires thoroughly considered structural reforms.

It should also be noted that the BRICS countries interact weakly with each other. Their economies are more aimed at cooperating with the US and the European Union. The total volume of internal turnover of the BRICS countries is 320 billion USD (2014), of which 65\% accounts for trade with China. BRICS trade turnover with the EU and US is almost 2 trillion USD, and China's trade turnover with other countries is 4.5 trillion USD. The annual turnover of only China and South Korea is 300 billion USD (almost as much as all the BRICS countries together) (Wikipedia, 2016). Thus, if we consider the turnover of Russia and 
China, China accounted for $11 \%$ of foreign trade turnover of Russia, and Russia $-2 \%$ of foreign trade turnover of China.

So, one can hardly speak of mutually beneficial cooperation in the presence of such differences between the countries. The BRICS countries are located on different continents, their economies are virtually not connected and focused mainly on the developed countries, the United States and the European Union, where the purchasing power of the population is much higher than in the developing countries. This geographical location increases the cost of economic transactions between the BRICS member countries, as they are not interconnected by regular shipping routes.

Today, the views of the economists on the prospects of BRICS have changed. Thus, Goldman Sachs specialized fund, which invested into BRICS, has decreased by 8 times for the period of 2010-2015. In the autumn 2015, Russia and Brazil were in recession, China growth slowed to minimum rates of 1990, and the economy of South Africa stopped. The Goldman Sachs investment project lost its appeal, which led to the closure of the investment fund on November, 82015 (Bootle, 2013).

Russia and Brazil are currently experiencing a prolonged economic crisis. The economic sanctions imposed on Russia in consequence of the events in Ukraine also have a significant negative impact on its economy. According to the International Monetary Fund (IMF) in 2015 the BRICS countries which showed negative growth were Brazil and Russia, 3.8\% and 3.7\% respectively. The IMF expects negative growth of their economies in 2016 as well. Unlike Russia and Brazil, China's economy in 2016 will grow by 6.3\%, India's economy - by 7.5\%, and even South Africa's economy - by $0.7 \%$ (Table 2) (International Monetary Fund, 2016).

Table 2

The rate of growth or decline of GDP in the BRICS and TICKS countries, $\%$

\begin{tabular}{|l|c|c|c|}
\hline \multicolumn{1}{|c|}{ Countries } & $\mathbf{2 0 1 4}$ & $\mathbf{2 0 1 5}$ & $\mathbf{2 0 1 6}$ (forecast) \\
\hline Russia & 0,6 & $-3,7$ & -1 \\
\hline Brazil & 0,1 & $-3,8$ & $-3,5$ \\
\hline India & 7,3 & 7,3 & 7,5 \\
\hline China & 7,3 & 6,9 & 6,3 \\
\hline South Korea & 3,3 & 2,7 & 3,2 \\
\hline Taiwan & 3,8 & 2,2 & 2,6 \\
\hline South Africa & 1,5 & 1,3 & 0,7 \\
\hline
\end{tabular}

Source: Own calculations based on International Monetary Fund.

Relative figures of foreign direct investment in the BRICS and TICKS countries are worthy of note (Table 3) (UNCTAD, 2016).

Russia experienced a dramatic decline in foreign investments from 31,668 million USD in 2010 to 9,825 million USD in 2015. Russia is losing its investment attractiveness in the global investment market.

The place of Russia and Brazil in the group of five countries was occupied by Taiwan and South Korea. These very countries actively attract foreign investment, directing them to the development of services and technology. Thus, today there is a new group of countries that might become the engine of the world economy - the TICKS group: Taiwan, India, China, Korea/South Korea, South Africa. This is due to the changes in global markets and in global demand: services, especially high technology ones, are becoming the most expensive product and have the greatest demand, and trade in raw materials is fading into the background. Global investment is channeled into high-tech industries, the development of which characterizes the TICKS economies. Thus, the volume of investments in the emerging markets are coming 
to the IT sector in China almost equal the volume of investments in the Chinese financial sector (Figure 1) (Copley Fund Researsch, 2015).

Foreign Direct Investment in the BRICS and TICKS Countries for the Period of 2010-2015 (million USD)

\begin{tabular}{|l|c|c|c|c|c|c|}
\hline \multicolumn{1}{|c|}{ Countries } & $\mathbf{2 0 1 0}$ & $\mathbf{2 0 1 1}$ & $\mathbf{2 0 1 2}$ & $\mathbf{2 0 1 3}$ & $\mathbf{2 0 1 4}$ & $\mathbf{2 0 1 5}$ \\
\hline Brazil & 83749 & 96152 & 76098 & 53060 & 73086 & 64648 \\
\hline Russia & 31668 & 36868 & 30188 & 53397 & 29152 & 9825 \\
\hline India & 27417 & 36190 & 24196 & 28199 & 34582 & 44208 \\
\hline China & 114734 & 123985 & 121080 & 123911 & 128500 & 135610 \\
\hline South Africa & 3636 & 4243 & 4559 & 8300 & 5771 & 1772 \\
\hline Taiwan & 2492 & -1957 & 3207 & 3598 & 2839 & 2415 \\
\hline South Korea & 9497 & 9773 & 9496 & 12767 & 9274 & 5042 \\
\hline
\end{tabular}

Source: Own calculations based on UNCTAD.

The share of Taiwan and Korea now accounts for at least 35\% in some investment funds, while Russia and Brazil receive about 3\% of the investment companies assets. According to Copley Fund Research, the share of the TICKS countries in the portfolio of an average investment fund in the emerging markets has increased from 40\% in April 2013 to the current 54\%. 63\% of these funds have invested at least 50\% of their assets in the TICKS countries, and only $10 \%$ of funds invest in emerging markets, the same funds are invested into BRICS (Wikipedia, 2016).

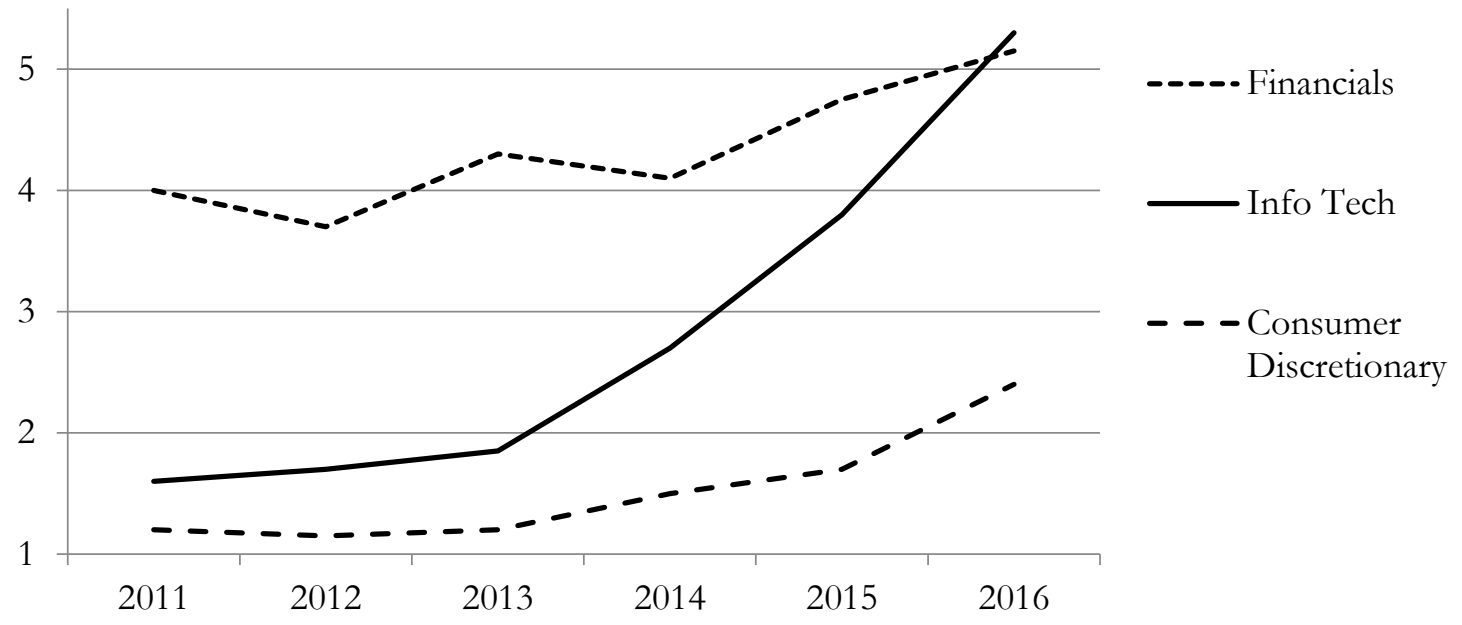

Figure 1. The share of investment in leading industries of China in 2011-2016 years, \% (as of January 1 of the respective year)

Source: Own calculations based Copley Fund Research.

The share of the TICKS countries in the total investment in emerging markets is increasing and is currently at about 54\%, while the share of the BRICS countries remains at 40\% (Figure 2) (Copley Fund Researsch, 2015). 


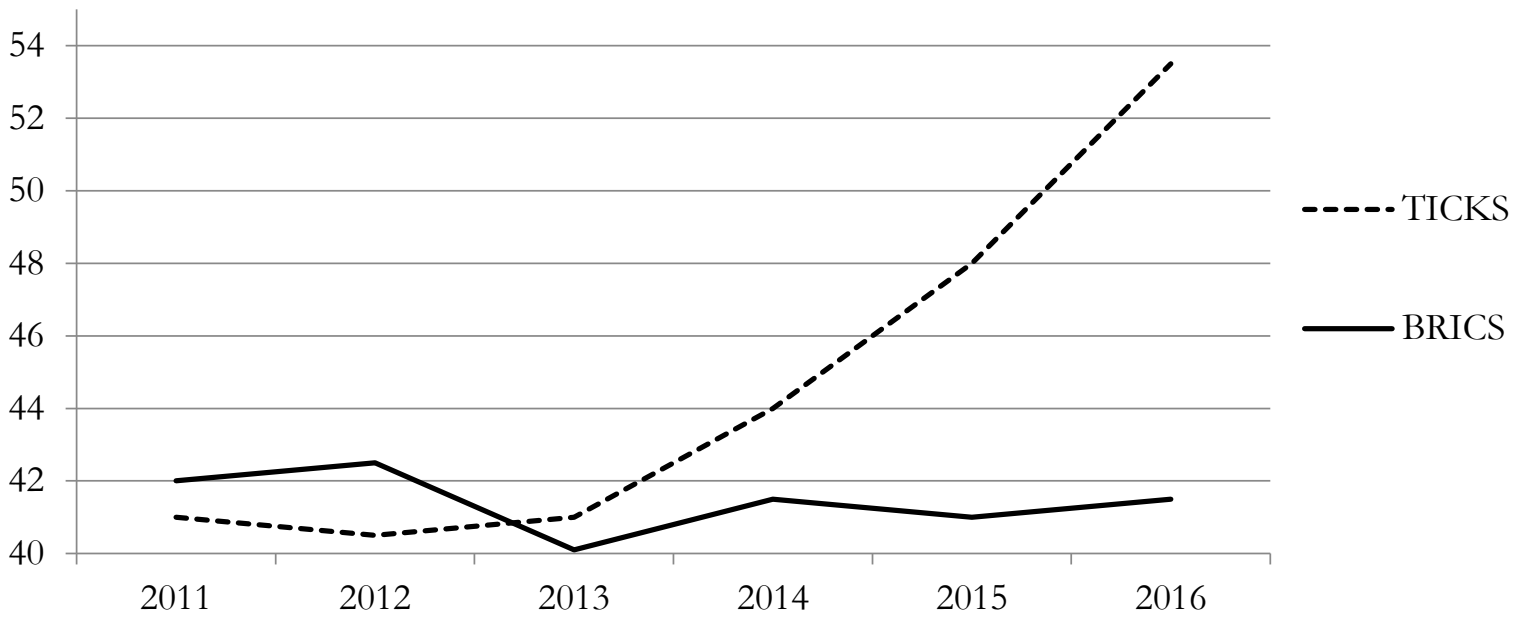

Figure 2. The share of the BRICS and TICKS countries in the total investments in emerging markets in the years 2011-2016,\% (as of January 1 of the respective year)

Source: Own calculations based on Copley Fund Researsch.

Thus, we can state the fact that TICKS has significant advantages over BRICS. However, there are a number of possible observations on the TICKS possible structure. According to the authors, it is more appropriate for TICKS to have Thailand, India, China, Korea, and Singapore as member states (TICKS *). That means that excluding three countries from BRICS - Russia, Brazil and South Africa is more reasonable than excluding two countries - Russia and Brazil.

The authors also argue that two countries in the TICKS group should be changed for the other ones - the place of Taiwan comes to Thailand, and Singapore takes place of South Africa.

The membership of South Korea in the new association does not cause doubt, given the presence of the country's powerful technology companies such as Samsung, LG, Daewoo and KIA. Taking into account the main criterion of forming TICKS, namely the country's place in the development of high-tech sector, the authors have to state that South Africa's economic structure does not meet this criterion, unlike the economy of Singapore. Besides, South Africa is the only TICKS country, which is located on another continent, which is a barrier to the economic integration.

The economy of Taiwan is more consistent with this criterion. However, we should remember the significant contradictions between China and Taiwan, which the authors believe might interfere with the effective functioning of TICKS. In addition to political and geographical aspects, there are purely economic ones.

Although the Republic of Korea, Taiwan and Singapore do not belong to emerging markets, according to Bootle R. (Bootle, 2013), they, however, belong to developing countries, according to the International Monetary Fund (IMF, 2016) and United Nations Conference on Trade and Development (UNCTAD, 2016) classifications. And the rates of their economic development in recent years are higher than in Russia, Brazil and South Africa.

Let us compare the rates of GDP growth in the TICKS and TICKS * countries. According to the International Monetary Fund (IMF) in 2015 the GDP growth in Singapore and Thailand was almost three times higher than the growth rate in South Africa and Taiwan respectively (Table 4) (International Monetary Fund, 2016). 
The rate of growth or decline of GDP in the TICKS and TICKS* countries, $\%$

\begin{tabular}{|l|c|c|c|}
\hline \multicolumn{1}{|c|}{ Countries } & $\mathbf{2 0 1 4}$ & $\mathbf{2 0 1 5}$ & $\mathbf{2 0 1 6}$ (forecast) \\
\hline South Africa & 1,5 & 1,3 & 0,7 \\
\hline Singapore & 4,6 & 4,7 & 4,8 \\
\hline Taiwan & 3,8 & 2,2 & 2,6 \\
\hline Thailand & 6,8 & 6,6 & 6,3 \\
\hline
\end{tabular}

Source: Own calculations based on International Monetary Fund.

The comparative figures of foreign direct investment in the TICKS and TICKS* countries are noteworthy (Table 5) (UNCTAD, 2016).

Table 5

Foreign Direct Investment in the TICKS and TICKS* Countries for the Period of 2010-2015 (million USD)

\begin{tabular}{|l|c|c|c|c|c|c|}
\hline Countries & $\mathbf{2 0 1 0}$ & $\mathbf{2 0 1 1}$ & $\mathbf{2 0 1 2}$ & $\mathbf{2 0 1 3}$ & $\mathbf{2 0 1 4}$ & $\mathbf{2 0 1 5}$ \\
\hline South Africa & 3636 & 4243 & 4559 & 8300 & 5771 & 1772 \\
\hline Singapore & 55076 & 48329 & 57150 & 66067 & 68496 & 65262 \\
\hline Taiwan & 2492 & -1957 & 3207 & 3598 & 2839 & 2415 \\
\hline Thailand & 9497 & 9773 & 9496 & 12767 & 9274 & 5042 \\
\hline
\end{tabular}

Source: Own calculations based on UNCTAD.

Significant difference in the volume of foreign direct investments is observed between Singapore and South Africa, where in 2010-2015 it almost annually exceeded 10 times, which also shows the existing advantage of Singapore and Thailand over South Africa, and Taiwan respectively.

Calculation of the share of foreign direct investment attracted over the years 2010-2015 in the total investment in developing countries, conducted for the BRICS, TICKS and TICKS* countries, revealed a situation that the BRICS countries during the whole period had an advantage over TICKS on this indicator, and the TICKS* countries gained an advantage over BRICS by the results of 2015 (Table o) (authors using the data of UNCTAD, 2016).

Graphic representation of the calculations made is shown in Figure 3 (authors using the data of UNCTAD, 2016).

Consequently, investors are increasingly focused on emerging markets, among which there is a new group of fast-growing economies - the TICKS * countries (Thailand, India, China, Korea, Singapore). These countries are actively developing high-tech industries, which are the most profitable ones; besides, international corporations are created there. The TICKS $*$ countries also show steady growth of macroeconomic indicators. 
Table 6

The Share of Foreign Direct Investment in the BRICS, TICKS and TICKS* Countries in Foreign Direct Investment in Developing Countries for the Period of 2010-2015 (million USD)

\begin{tabular}{|l|c|c|c|c|c|c|}
\hline \multicolumn{1}{|c|}{ Countries } & $\mathbf{2 0 1 1}$ & $\mathbf{2 0 1 2}$ & $\mathbf{2 0 1 3}$ & $\mathbf{2 0 1 4}$ & $\mathbf{2 0 1 5}$ & $\mathbf{2 0 1 6}$ \\
\hline Brazil & 83749 & 96152 & $\mathbf{7 6 0 9 8}$ & 53060 & $\mathbf{7 3 0 8 6}$ & 64648 \\
\hline Russia & 31668 & 36868 & 30188 & 53397 & 29152 & 9825 \\
\hline India & 27417 & 36190 & 24196 & 28199 & 34582 & 44208 \\
\hline China & 114734 & 123985 & 121080 & 123911 & 128500 & 135610 \\
\hline South Africa & 3636 & 4243 & 4559 & 8300 & 5771 & 1772 \\
\hline Total BRICS & 261204 & 297438 & 256121 & 266867 & 271091 & 256063 \\
\hline Share BRICS in FDIDC & 41,77 & 44,38 & 38,88 & 40,29 & 38,81 & 33,50 \\
\hline Taiwan & 2492 & 1957 & 3207 & 3538 & 2839 & 18541 \\
\hline India & 27417 & 36190 & 24196 & 28199 & 34582 & 44208 \\
\hline China & 114734 & 123985 & 121080 & 123911 & 128500 & 135610 \\
\hline Korea & 9497 & 9773 & 9496 & 12767 & 9274 & 5042 \\
\hline South Africa & 3636 & 4243 & 4559 & 8300 & 5771 & 1772 \\
\hline Total TICKS & 157776 & 176148 & 162538 & 176715 & 180966 & 205173 \\
\hline Share TICKS in FDIDC & 25,23 & 26,28 & 24,67 & 26,68 & 25,91 & 26,84 \\
\hline Thailand & 14568 & 3271 & 16517 & 16652 & 3537 & 10845 \\
\hline India & 27417 & 36190 & 24196 & 28199 & 34582 & 44208 \\
\hline China & 114734 & 123985 & 121080 & 123911 & 128500 & 135610 \\
\hline Korea & 9497 & 9773 & 9496 & 12767 & 9274 & 5042 \\
\hline Singapore & 55076 & 48329 & 57150 & 66067 & 68496 & 65262 \\
\hline Total TICKS* & 221292 & 221548 & 228439 & 247596 & 244389 & 260967 \\
\hline Share TICKS* in FDIDC & 35,39 & 33,06 & 34,68 & 37,38 & 34,99 & 34,14 \\
\hline FDI in developing countries (FDIDC) & 625320 & 670149 & 658774 & 662406 & 698494 & 764370 \\
\hline
\end{tabular}

Source: Own calculations based on UNCTAD

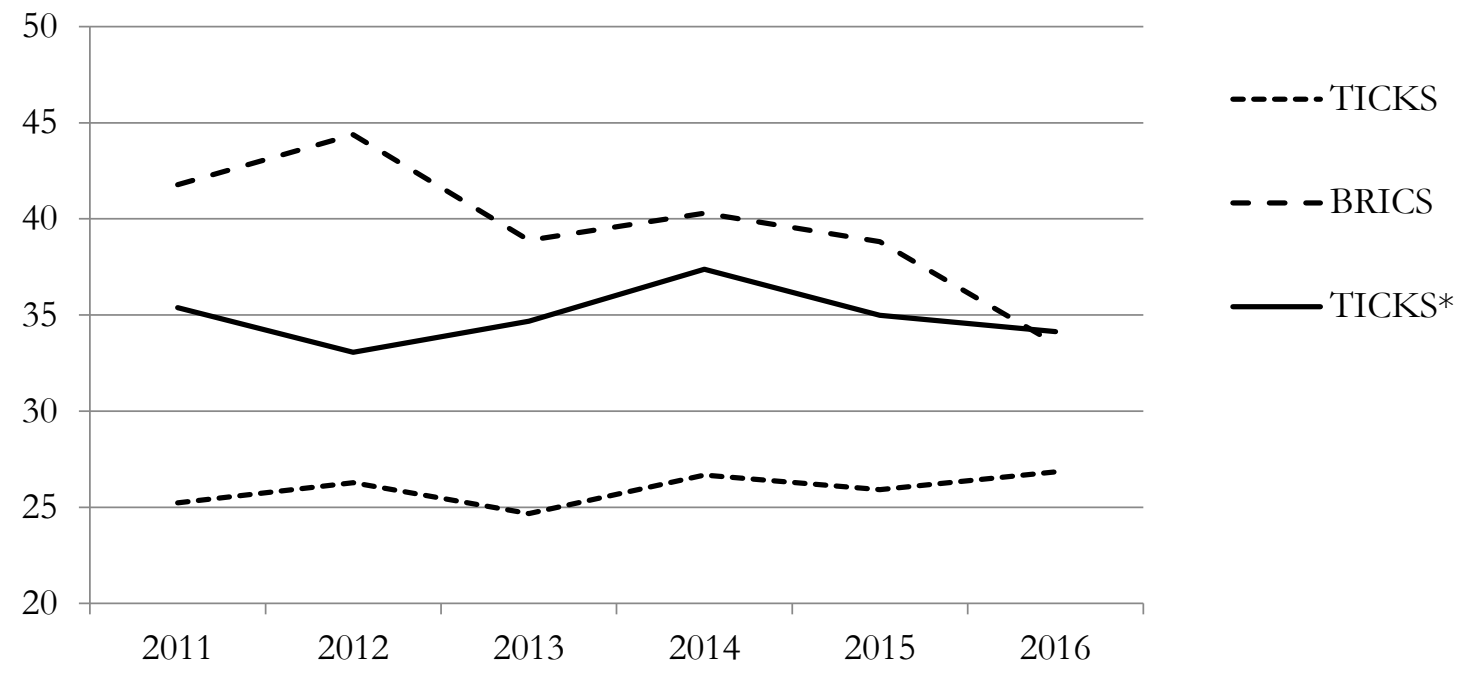

Figure 3. The share of FDI in total FDI in developing countries in the years 2011-2016,\% (as of January 1 of the respective year)

Source: Own calculations based on UNCTAD. 


\section{CONCLUSIONS}

Thus, under the influence of globalization, changes in all spheres of the international community are intensified. The former leaders of the world economy are replaced by the new ones, due to the changes in the global demand and investment priorities. So, the BRICS group of countries that were considered to be the engines of the global economy finishes its existence - the TICKS group comes in its place. The TICKS is a grouping of five rapidly developing countries (Taiwan, China, India, Korea, South Africa). The TICKS has significant advantages over the BRICS. However, the authors suggest a new membership of TICKS* Thailand, India, China, Korea, Singapore (TICKS*). In other words, it is more reasonable to exclude three countries from the BRICS - Russia, Brazil and South Africa - than to exclude two of them - Russia and Brazil. And two more countries in the TICKS group, according to the authors, should be changed for the other ones - the place of Taiwan comes to Thailand, and Singapore takes place of South Africa, as the profiles of those economies meet more the priorities of the modern global economy, and they show a steady increase in the volume of foreign investment and GDP.

\section{REFERENCES}

Aslund, A. (2016, February). BRIKS nachinayet tonut [BRICS begins to sink)]. Liga.net. Retrieved 03 November 2016 from http:/ / finance.liga.net/economics/2016/2/15/opinion/47005.htm. [In Russian].

Balitskiy, S., Bilan, Y., \& Strielkowski, W. (2014). Energy security and economic growth in the European Union. Journal of Security \& Sustainability Issues, 4(2), 123-130.

Banioniene, J., \& Dagiliene, L (2017). Opportunities to Catch Up Advanced Countries by Investing in Technologies. Montenegrin Journal of Economics, 13(1), 11-123.

Bootle, R. (2013, July 14). Economic focus should shift from the BRICs to Africa's emerging markets. The Telegraph. Retrieved 03 November 2016 from http://www.telegraph.co.uk/finance/comment/rogerbootle/10178956/ Economic-focus-should-shift-from-the-BRICs-to-Africas-emerging-markets.html.

BRICS. (2015). BRICS in Numbers. Retrieved 03 November 2016 from http://en.brics2015.ru.

Copley Fund Research. (2015, September). Healthcare - Early Stages, Big Opportunity. Retrieved 03 November 2016 from http://www.copleyfundresearch.com/2015/09/.

International Monetary Fund. (2016, April). World Economic Outlook (WEO). Too Slow for Too Long. Retrieved 03 November 2016 from http://www.imf.org/external/pubs/ft/weo/2016/01/pdf/text.pdf.

Johnson, S. (2016, January 28). The Brics are dead. Long live the Ticks. Financial Times. Retrieved 03 November 2016 from http://www.ft.com/cms/s/2/b1756028-c355-11e5-808f-8231cd71622e.html\#ixzz473.

O'Neill, J. (2001, November 30). Building Better Global Economic BRICs. Global Economics Paper, 66. Retrieved 03 November 2016 from http://www.goldmansachs.com/our-thinking/archive/archive-pdfs/build-betterbrics.pdf.

Mamedov, O., Movchan, I., Ishchenko-Padukova, O., \& Grabowska, M. (2016). Traditional Economy: Innovations, Efficiency and Globalization. Economics \& Sociology, 9(2), 61-71. doi:10.14254/2071-789X.2016/9-2/4.

Movchan, A. (2015, July). Lozhnaya nadezhda. Pochemu BRIKS ne budet rabotat (False hope. Why BRICS will not work). Slon Magazine. Retrieved 03 November 2016 from https://slon.ru/posts/53884.

Szurlej, A., Ruszel, M., \& Olkuski, T. (2015). Will natural gas be competitive fuel?, Rynek Energii, 120(5), 3-10.

The Heritage Foundation. (2016). Global Index of Economic Freedom. Country Rankings. Retrieved 03 November 2016 from http://www.heritage.org/index/ranking.

Transparency International. (2016). Corruption Perceptions Index 2015. Retrieved 03 November 2016 from http://www.transparency.org/cpi2015\#results-table.

UNCTAD. (2016). World Investment Report 2016. Investor Nationality: Policy Challenges. Retrieved 03 November 2016 from http://unctad.org/en/PublicationsLibrary/ wir2016_en.pdf.

Verner, T. (2011). National Competitiveness and Expenditure on Education, Research and Development. Journal of Competitiveness, 3(2), 3-10. 
Wikipedia. (2016). BRICS. Retrieved 03 November 2016 from http://ru.wikipedia.org/wiki/БРИКC\#cite_note-17. Wikipedia.(2016). BRIKS [BRICS]. Retrieved 03 November 2016 from https://uk.wikipedia.org/wiki/BRIC.

Yerznkyan, B. H. (2016). The Strategy for Russia's Breakthrough to the Future: Lvov's Legacy. Montenegrin Journal of Economics, 12(2), 89-100.

9th BRICS Summit, Xiamen, China. (2017, September, 3-5). Retrieved from http://www.xinhuanet.com/english/special/brics2017/index.htm. 